\title{
Knowledge and attitudes of healthcare professionals and the impact on willingness to donate organs: a tertiary hospital survey
}

\author{
Wei Loon $\underline{O}^{1}$, MB BCh BAO, Jea Sheng Ong ${ }^{1}$, MB BCh BAO, James William Foong ${ }^{1}$, MB BCh BAO, \\ Mohammad Moshaddeque Hossain ${ }^{2}$, MBBS, PhD, Nirmala Devi Baskaran ${ }^{3}$, MRCP, MMed, \\ Hasdy Haron $^{4}$, MBBS, Raghu Varadarajan ${ }^{1}$, MCh, FRCSEd
}

INTRODUCTION Healthcare professionals (HCPs) working in critical care areas play an important role in the organ donation (OD) process. We studied HCPs' own willingness to be organ donors and its association with sociodemographic factors as well as their knowledge and attitudes about OD and transplantation.

METHODS A cross-sectional survey of HCPs working in four critical care units in a major transplant centre in Malaysia was undertaken using a validated structured questionnaire. Responses were analysed using multivariable analysis with willingness to donate as the dependent variable.

RESULTS Of the 412 respondents (response rate $98.1 \%$ ), the majority were nurses (60.4\%), Malay (71.1\%) and female $(77.2 \%)$. Overall, $68.0 \%$ were willing to donate. The independent predictors of willingness to donate were profession $(p<0.001)$ and the Hindu religion $(p=0.001)$. Ethnicity $(p=0.003)$, religious belief $(p<0.001)$, knowledge $(p=0.016)$, belief in brain death $(p=0.018)$ and confidence in transplantation $(p<0.001)$ also independently correlated with willingness to donate, while attitudes to OD did not. Of those willing to donate, only $37.3 \%$ were carrying a donor card and only $63.1 \%$ had informed their family of their intention to donate.

CONCLUSION Although willingness to donate was higher in critical care HCPs than HCPs in general, significant knowledge gaps as well as certain beliefs and perceptions that could pose a barrier to OD were identified in this group. Measures to improve OD rates in Malaysia should include targeted educational programmes for HCPs working in critical care areas.

Keywords: brain death, critical care, health personnel, organ transplantation, tissue and organ procurement

\section{INTRODUCTION}

The concept of brain death (BD) was officially recognised in Malaysia by the Malaysian Medical Council in 1993 with the publication of the Consensus Statement on BD.(1) However, organ donation (OD) was sporadic until the first heart transplant in 1997, when interest in BD and deceased OD revived. ${ }^{(2)}$ In an effort to improve OD rates, tissue organ procurement teams were established in hospitals throughout Malaysia. ${ }^{(2-4)}$ Hospital staff specifically identified for this purpose included doctors (responsible for donor detection, diagnosis of BD, referral and consent), nurses (to reinforce the aforementioned functions and support the family) and other staff responsible for the transport of organs and speedy return of the donor's remains to the next of kin. ${ }^{(3,4)}$

In spite of these efforts, Malaysia's deceased OD rate in 2015 was only one per million population (pmp), among the lowest in the world, although there were 21,513 patients on the waiting list. ${ }^{(5,6)}$ Developed countries such as Spain (40.15 pmp), the United States (28.21 pmp) and the United Kingdom (20.26 pmp) have achieved substantially better deceased OD rates. ${ }^{(7)}$ Other Muslim countries such as Turkey and Iran have recorded deceased OD rates of $6.00 \mathrm{pmp}$ and $10.21 \mathrm{pmp}$, respectively, while neighbouring countries such as Singapore and Thailand attained 3.93 pmp and 3.03 pmp, respectively. ${ }^{(7)}$
The low donation rate in Malaysia is concerning and has been highlighted in previous studies. ${ }^{(2,8,9)}$ Malaysia's multiracial and religious society consists of three major ethnicities, Malay $(68.6 \%)$, Chinese $(23.4 \%)$ and Indian (7.0\%). ${ }^{(10)}$ Awareness of deceased OD has been found to be low, with less than half $(34.9 \%-44.3 \%)$ of the general population being reported to be willing to donate. ${ }^{(8,11,12)}$ Lack of trust in the medical system, cultural-religious attitudes, a desire to be buried whole, and insufficient information on OD were common reasons cited for unwillingness to donate. ${ }^{(8)}$ Loch et al and Wong reported a difference in acceptance of OD among different ethnic groups: Malays, who make up the largest proportion of the population, were less willing to donate..$^{(8,11)}$ Another study stated that only $34.8 \%$ of the Muslim population were willing to donate. ${ }^{(13)}$ However, other researchers suggested that religious and cultural factors may not influence the decision to donate. ${ }^{(12,13)}$ Instead, possible reasons were lack of access to information on OD and not being convinced of the benefits of OD. ${ }^{(12,13)}$

Another factor that could contribute to low OD rates is the failure of healthcare professionals (HCPs) to identify donors, obtain their consent and procure organs. ${ }^{(9)}$ This has been the subject of several studies around the world. ${ }^{(14-21)}$ An American study showed that HCPs' attitudes played a major

${ }^{1}$ Department of Surgery, ${ }^{2}$ Department of Epidemiology and Public Health, Perdana University-Royal College of Surgeons in Ireland, Selangor, ${ }^{3}$ Department of Nephrology, Hospital Kuala Lumpur, ${ }^{4}$ National Transplant Resource Centre, Kuala Lumpur, Malaysia

Correspondence: Prof Raghu Varadarajan, Associate Professor and Lead, Department of Surgery, Perdana University-Royal College of Surgeons in Ireland School of Medicine, Block B and D1, Level 1, MAEPS Building, MARDI Complex, Jalan MAEPS Perdana, 43400 Serdang, Selangor, Malaysia. raghu@perdanauniversity.edu.my 
role in approaching families for donation and that their medical knowledge did not affect the OD process. ${ }^{(21)}$ Studies in Spain and Nigeria have shown that the medical profession and knowledge of $\mathrm{BD}$ were strongly correlated with $\mathrm{HCPs}^{\prime}$ willingness to donate. ${ }^{(14,15,17)}$ In the Islamic world, $90 \%$ of HCPs in Turkey were willing to donate their own organs and $83 \%$ of HCPs from Qatar supported OD. ${ }^{(18,20)}$ Abidin et al and Rozaidi et al concluded that general HCPs in Malaysia had low levels of agreement to OD, as only $47.8 \%$ and $49.5 \%$ of them, respectively, were willing to donate their own organs, consistent with that of the general population. ${ }^{(2,9)} \mathrm{HCPs}^{\prime}$ acceptance and declaration of $\mathrm{BD}$, passivity in approaching family, and cultural and religious differences may affect the OD process. ${ }^{(9)}$

A review of 45 studies published by Walters in 2009 showed that the responsibility for OD may be best placed within the domain of specialist personnel working in critical care areas. ${ }^{(22)}$ These professionals are directly involved in recognising and diagnosing BD; they establish a relationship with the family early on and may advocate OD once the diagnosis of BD has been confirmed. ${ }^{(23)}$ They are also responsible for contacting transplant coordinators and initiating the OD process. ${ }^{(9,23,24)}$ These HCPs also play a vital role in nursing the potential multiorgan donor. ${ }^{(24)}$ In Malaysia, the OD process has been outlined by the National Transplant Resource Centre. ${ }^{(25)}$ HCPs working in this domain must therefore have adequate experience, knowledge, skills and positive attitudes, as they have the ability to influence OD rates. Longer waiting lists and low OD rates may be a reflection of their reticence, leading to lack of transplantable organs.

Local and worldwide studies showed that HCPs were more likely to request donations from families if they were personally willing to donate. ${ }^{(9,21)}$ This is especially relevant for HCPs working in critical care areas, as they are directly involved in the OD process. In a large-scale international study surveying such professionals from 11 developed countries, an average of $79.3 \%$ were willing to donate their own organs. ${ }^{(26)}$ Willingness to donate in this group of professionals has not been studied in the Malaysian context and hence merits scrutiny. We hypothesised that the knowledge and attitudes of HCPs working in critical care areas would correlate positively with the HCPs' personal willingness to donate organs. We also believed that religion and religious beliefs may correlate with their willingness to donate.

This study examined the association between HCPs' knowledge of BD, OD and organ transplantation and their willingness to donate. In addition, we examined associations among specific attitudes towards BD and OD, confidence in transplantation and religious beliefs, and the HCPs' willingness to donate.

\section{METHODS}

A cross-sectional survey was carried out in July 2015 in Hospital Kuala Lumpur, a major transplant centre in Kuala Lumpur, Malaysia. The study population consisted of doctors and nurses (medical officers, specialists, consultants, registered nurses, sisters and matrons) working in the following critical care areas: General Medical Intensive Care Unit (ICU); Neurosurgery ICU;
Neurology; and Emergency and Trauma. The target population size was 565, which was the total number of HCPs working in the above areas. The study was conducted and reported according to recommendations from the STROBE (Strengthening the Reporting of Observational Studies) Statement. ${ }^{(27)}$ It was registered under the National Medical Research Register (NMRR) with ID number NMRR-14-1790-23450 S5 R0. Ethical approval was given by Malaysia's Medical Research and Ethics Committee and the Perdana University Internal Review Board (PUIRB-HR0090).

A questionnaire was constructed based on existing literature and clinical experience. ${ }^{(1,18,28-32)}$ It contained 51 items and included ten demographic features, 25 knowledge questions and 16 attitude questions. Collected sociodemographic data included profession, position, gender, age, religion and ethnicity. The questionnaire was divided into two sections, the first on BD and the second on OD and transplantation. Each knowledge and attitude question was assessed using a five-point Likert scale with the responses 'Definitely not', 'Probably not', 'Unsure', 'Probably yes' and 'Definitely yes'. The sum of the overall knowledge scores was calculated out of 25 questions: the maximum total OD and transplantation knowledge score was 10 , while the total BD knowledge score was 15 . Five questions specifically concerned knowledge on BD tests. Respondents' attitudes were grouped according to theme: religious attitudes, attitudes towards BD, confidence towards transplantation and attitudes towards OD.

We assessed the questionnaire qualitatively by face and content validation. For this, ten experts in the fields of medicine, surgery, psychology and transplantation examined early versions of the questionnaire. The final version incorporated the experts' comments. The questionnaire, participant information sheet (PIS) and consent form were constructed in English and translated into Malay. An independent back translation was performed to check for validity. An option of either language was offered to our study population.

Participants from the above critical care areas were verbally briefed and handed a copy of the PIS. After obtaining written consent, the questionnaire was distributed to the respondents individually. Completed questionnaires were separated from the PIS and consent forms so that anonymity was maintained. Responses were coded into IBM SPSS Statistics version 22.0 (IBM Corp, Armonk, NY, USA) for statistical analysis.

Data was analysed using IBM SPSS Statistics and Stata version 14 (StataCorp, College Station, TX, USA). Questionnaires that were less than $80 \%$ complete were excluded entirely to avoid any analysis being unjustly skewed. For questionnaires that were more than $80 \%$ complete, only missing data for particular items were excluded. These exclusion criteria were determined during the study design phase to eliminate the possibility of postentry exclusion bias. For knowledge questions, the Likert scale responses were collapsed into a right or wrong answer, with every right answer being given a score of 1. Questions pertaining to attitudes were analysed quantitatively. 'Definitely yes' and 'Probably yes' were grouped together as 'Yes', while 'Unsure', 'Definitely not' and 'Probably not' were grouped as 'No/unsure', as the absolute numbers for some Likert scale responses were too 
Table I. Association of sociodemographic data with willingness to donate $(n=412)$.

\begin{tabular}{|c|c|c|c|c|c|c|c|c|c|c|c|}
\hline \multirow[t]{2}{*}{ Parameter } & \multirow[t]{2}{*}{ No. (\%) } & \multicolumn{3}{|c|}{$\begin{array}{c}\text { Willingness to } \\
\text { donate (no. [\%])* }\end{array}$} & \multirow[t]{2}{*}{ p-value } & \multicolumn{3}{|c|}{ Univariable analysis } & \multicolumn{3}{|c|}{ Multivariable analysis } \\
\hline & & Yes & $\begin{array}{l}\text { No/ } \\
\text { unsure }\end{array}$ & $\begin{array}{l}\text { No } \\
\text { answer }\end{array}$ & & COR & $95 \% \mathrm{Cl}$ & p-value & aOR & $95 \% \mathrm{Cl}$ & p-value \\
\hline $\operatorname{Age}^{\dagger}(y r)$ & $29.37 \pm 6.08$ & & & & & 1.05 & $1.01-1.10$ & 0.011 & 1.00 & $0.96-1.04$ & 0.934 \\
\hline Gender & & & & & $<0.001$ & & & & & & \\
\hline Male & $94(22.8)$ & $78(83.0)$ & $16(17.0)$ & 0 & & 2.79 & $1.55-5.01$ & 0.001 & - & - & - \\
\hline Female & $318(77.2)$ & $201(63.6)$ & $115(36.4)$ & 2 & & 1.00 & - & - & - & - & - \\
\hline Profession & & & & & $<0.001$ & & & & & & \\
\hline Doctor & $163(39.6)$ & $142(87.1)$ & $21(12.9)$ & 0 & & 5.43 & $3.22-9.15$ & $<0.001$ & 4.29 & $2.37-7.76$ & $<0.001$ \\
\hline Nurse & $249(60.4)$ & $137(55.5)$ & $110(44.5)$ & 2 & & 1.00 & - & - & 1.00 & - & - \\
\hline Designation* & & & & & $<0.001$ & & & & & & \\
\hline Consultant & $12(2.9)$ & $9(75.0)$ & $3(25.0)$ & 0 & & 2.51 & $0.66-9.52$ & 0.175 & - & - & - \\
\hline Specialist & $30(7.4)$ & $25(83.3)$ & $5(16.7)$ & 0 & & 4.19 & $1.55-11.33$ & 0.005 & - & - & - \\
\hline Medical officer & $123(30.1)$ & $110(89.4)$ & $13(10.6)$ & 0 & & 7.09 & $3.77-13.33$ & $<0.001$ & - & - & - \\
\hline Sister/matron & $16(3.9)$ & $9(60.0)$ & $6(40.0)$ & 1 & & 1.26 & $0.43-3.65$ & 0.675 & - & - & - \\
\hline Registered nurse & $227(55.6)$ & $123(54.4)$ & $103(45.6)$ & 1 & & 1.00 & - & - & - & - & - \\
\hline Ethnicity & & & & & $<0.001$ & & & & & & \\
\hline Malay & $293(71.1)$ & $177(60.8)$ & $114(39.2)$ & 2 & & 1.00 & - & - & 1.00 & - & - \\
\hline Chinese & $50(12.1)$ & $43(86.0)$ & $7(14.0)$ & 0 & & 3.96 & $1.72-9.10$ & 0.001 & 1.84 & $0.74-4.58$ & 0.188 \\
\hline Indian & 60 (14.6) & $54(90.0)$ & $6(10.0)$ & 0 & & 5.80 & $2.42-13.92$ & $<0.001$ & 3.89 & $1.57-9.61$ & 0.003 \\
\hline Others & $9(2.2)$ & $5(55.6)$ & $4(44.4)$ & 0 & & 0.81 & $0.21-3.06$ & 0.75 & 0.52 & $0.12-2.18$ & 0.369 \\
\hline
\end{tabular}

*Percentages were calculated based on available data $(n=408)$. †Data presented as mean \pm standard deviation. aOR: adjusted odds ratio; $\mathrm{Cl}$ : confidence interval; cOR: crude odds ratio

few to allow for appropriate statistical analysis. 'Unsure' was taken as a negative response for all questions, because being unsure showed a tendency to support a negative attitude as compared to a positive one.

Descriptive statistics including percentage, mean and standard deviation were used to summarise the variables, as appropriate. Demographics and attitudes were cross-tabulated with willingness to donate as the dependent variable, and Pearson's chi-square test was used to examine for statistical significance. Univariable logistic regression analysis was used to identify associations between demographics, knowledge scores and attitudes, with willingness to donate as the dependent variable. Multivariable logistic regression analysis was also used to adjust the odds for each significant independent variable. Kendall's tau-b correlation coefficient and Spearman's rank correlation coefficient were used to check for correlation prior to input into the model. Results of the univariable and multivariable analyses were displayed as odds ratios and 95\% confidence intervals $(\mathrm{Cl})$. For categorical variables, the odds ratios were relative to the reference population. Statistical tests used were two-tailed and $p$-values $<0.05$ were considered significant.

\section{RESULTS}

Of the 565 HCPs employed in the critical care areas listed, 420 were available for the study. However, seven declined to participate. Data from another respondent was excluded due to non-completion of over $80 \%$ of the questionnaire, leaving a total of 412 respondents. Missing data was less than $6 \%$ for all variables. The contacted population response rate was $98.1 \%$, while the total eligible population response rate was $72.9 \%$. The mean age of the respondents was $29.37 \pm 6.08$ years. The majority were nurses $(60.4 \%)$, female $(77.2 \%)$ and Malay $(71.1 \%)$.

Table I shows the association between sociodemographics and willingness to donate. Male respondents were more willing to donate than female respondents (crude odds ratio [COR] 2.79, $95 \% \mathrm{Cl} 1.55-5.01, \mathrm{p}=0.001)$. Doctors were more willing to donate than nurses (cOR 5.43, 95\% Cl 3.22-9.15, p < 0.001). Indians (cOR 5.80, 95\% Cl 2.42-13.92, p < 0.001) and Chinese (cOR 3.96, 95\% Cl 1.72-9.10, $\mathrm{p}=0.001$ ) were significantly more willing to donate than Malays. Age initially showed a significant association with willingness to donate in univariable logistic regression analysis (COR 1.05, 95\% $\mathrm{Cl} 1.01-1.10, \mathrm{p}=0.011)$. However, in the multivariable logistic regression analysis, which included age, profession and ethnicity as independent variables, age (adjusted odds ratio [aOR] 1.00, 95\% Cl 0.96-1.04, p = 0.934) was no longer significant. The association remained significant for doctors (aOR 4.29, 95\% Cl 2.37-7.76, p < 0.001) and Indian ethnicity only (aOR 3.89, 95\% Cl 1.57-9.61, p = 0.003). Religion, position and gender were excluded from the multivariable logistic regression model. Religion was strongly associated with ethnicity (tau-b 0.951), and position (tau-b 0.874) and gender (tau-b 0.471) with profession. Ethnicity and religion are highly correlated in Malaysia. Ethnic Malays are all Muslims, as set out in the Malaysian Constitution; the majority of Chinese are Buddhists, and the majority of Indians are Hindus.

Table II shows the association between $\mathrm{HCPs}^{\prime}$ religion and religious beliefs and their willingness to donate. Univariable logistic regression analysis showed that Christians (COR 4.86, 95\% 


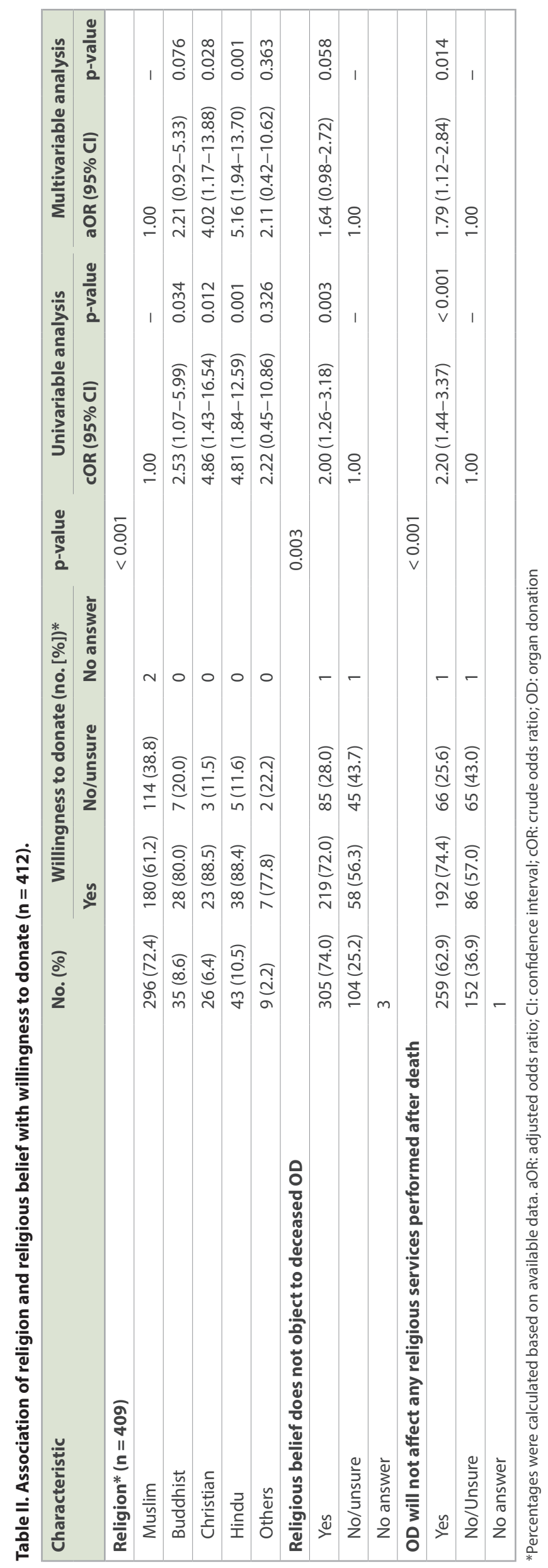

Table III. Association of knowledge with willingness to donate.

\begin{tabular}{|llll|}
\hline Knowledge score & \multicolumn{3}{c|}{ Willingness to donate } \\
\cline { 2 - 4 } & Mean \pm SD & COR $(95 \%$ CI) & p-value \\
\hline $\begin{array}{l}\text { Total brain death } \\
\text { (15 items) }\end{array}$ & $8.39 \pm 2.78$ & $1.21(1.11-1.31)$ & $<0.001$ \\
\hline $\begin{array}{l}\text { Brain death test* } \\
\text { (5 items) }\end{array}$ & $3.13 \pm 0.94$ & $1.32(1.05-1.65)$ & 0.016 \\
\hline $\begin{array}{l}\text { Total organ } \\
\text { donation+transplantation } \\
\text { (10 items) }\end{array}$ & $6.90 \pm 1.72$ & $1.13(1.00-1.28)$ & 0.05 \\
\hline Overall (25 items) & $15.35 \pm 3.62$ & $1.15(1.08-1.22)$ & $<0.001$ \\
\hline
\end{tabular}

*Brain death test score is a subcategory of total brain death knowledge score. $\mathrm{Cl}$ : confidence interval; cOR: crude odds ratio; SD: standard deviation

Cl 1.43-16.54, $\mathrm{p}=0.012$ ), Buddhists (cOR 2.53, 95\% Cl 1.07-5.99, $\mathrm{p}=0.034$ ) and Hindus (cOR 4.81, 95\% Cl 1.84-12.59, $\mathrm{p}=0.001$ ) were significantly more willing to donate than Muslims. HCPs who believed that their religion did not object to deceased OD (cOR 2.00, 95\% Cl 1.26-3.18, $\mathrm{p}=0.003$ ) were more willing to donate. Similarly, those who believed that OD would not affect religious services (cOR 2.20, 95\% $\mathrm{Cl} 1.44-3.37, \mathrm{p}<0.001$ ) were more willing to donate. In multivariable logistic regression analysis adjusted for religion and religious beliefs, Hindus (aOR 5.16, 95\% Cl 1.94-13.70, $\mathrm{p}=0.001$ ) and Christians (aOR 4.02, 95\% Cl 1.17-13.88, $\mathrm{p}=0.028$ ) remained significantly more willing to donate. Similarly, HCPs who believed that OD would not affect religious services remained more willing to donate (aOR 1.79, 95\% Cl 1.12-2.84, $\mathrm{p}=0.014$ ), but HCPs who felt that their religious belief was not opposed to deceased OD were no longer significantly more willing to donate (aOR 1.64, 95\% Cl 0.98-2.72, $\mathrm{p}=0.058)$.

Table III illustrates that willingness to donate was significantly associated with overall knowledge score (cOR 1.15, 95\% $\mathrm{Cl} 1.08-1.22, \mathrm{p}<0.001)$. It was also significantly associated with total BD knowledge score (COR 1.21, 95\% Cl 1.11-1.31, $\mathrm{p}<0.001)$ and BD test score (COR 1.32, 95\% Cl 1.05-1.65, $\mathrm{p}=0.016)$, and slightly associated with OD and transplantation knowledge score (cOR 1.13, 95\% Cl 1.00-1.28, p = 0.05).

The odds of HCPs' willingness to donate increased to $3.92(95 \% \mathrm{Cl} 2.13-7.23, \mathrm{p}<0.001)$ when they were convinced of the existence of $\mathrm{BD}$, by $1.83(95 \% \mathrm{Cl} 0.98-3.43, \mathrm{p}=0.059)$ when they believed that doctors could reliably diagnose $\mathrm{BD}$, and by $2.19(95 \% \mathrm{Cl} 1.41-3.39, \mathrm{p}<0.001)$ when they felt confident to explain BD to a patient's family member (Table IV). HCPs who believed that organ transplantation is a good form of treatment (cOR 2.75, 95\% Cl 1.68-4.49, p < 0.001), were willing to accept a deceased donor organ ( $\mathrm{COR} 4.36,95 \% \mathrm{Cl} 2.77-6.86, \mathrm{p}<0.001$ ) and believed that the success rate of transplantation was high (COR $2.20,95 \% \mathrm{Cl} 1.39-3.48, \mathrm{p}=0.001$ ) had greater odds of donating their organs. In multivariable logistic regression analysis, being convinced of the existence of BD (aOR 2.30, 95\% Cl 1.16-4.56, $\mathrm{p}=0.018$ ) and being willing to accept a deceased donor organ for transplantation (aOR 3.20, 95\% Cl 1.97-5.21, p < 0.001) were identified as independent predictors of willingness to donate after adjusting for other variables. 
Original Article

Table IV. Association of attitudes towards brain death and organ transplantation with willingness to donate.

\begin{tabular}{|c|c|c|c|c|c|c|c|c|c|}
\hline \multirow[t]{2}{*}{ Question } & \multirow[t]{2}{*}{ No. (\%) } & \multicolumn{3}{|c|}{ Willingness to donate (no. [\%])* } & \multirow[t]{2}{*}{ p-value } & \multicolumn{2}{|c|}{ Univariable analysis } & \multicolumn{2}{|c|}{ Multivariable analysis } \\
\hline & & Yes & No/unsure & No answer & & cOR $(95 \% \mathrm{CI})$ & p-value & aOR $(95 \% \mathrm{CI})$ & p-value \\
\hline \multicolumn{10}{|l|}{ Belief in brain death } \\
\hline $\begin{array}{l}\text { How convinced are you of the existence of a clinical state called brain } \\
\text { death? }\end{array}$ & & & & & $<0.001$ & & & & \\
\hline Yes & $360(87.4)$ & $259(72.3)$ & $99(27.7)$ & 2 & & $3.92(2.13-7.23)$ & $<0.001$ & $2.30(1.16-4.56)$ & 0.018 \\
\hline No/unsure & $50(12.1)$ & $20(40.0)$ & $30(60.0)$ & 0 & & 1.00 & - & - & - \\
\hline No answer & 2 & & & & & & & & \\
\hline In your opinion, can doctors reliably diagnose brain death? & & & & & 0.057 & & & & \\
\hline Yes & $367(89.1)$ & $254(69.6)$ & $111(30.4)$ & 2 & & $1.83(0.98-3.43)$ & 0.059 & - & - \\
\hline No/unsure & $45(10.9)$ & $25(55.6)$ & $20(44.4)$ & 0 & & 1.00 & - & - & - \\
\hline No answer & 0 & & & & & & & & \\
\hline $\begin{array}{l}\text { Do you feel confident to explain what brain death is to a patient's } \\
\text { family members? }\end{array}$ & & & & & $<0.001$ & & & & \\
\hline Yes & $283(68.7)$ & $208(73.5)$ & $75(26.5)$ & 0 & & $2.19(1.41-3.39)$ & $<0.001$ & $1.35(0.82-2.23)$ & 0.242 \\
\hline No/unsure & $129(31.3)$ & $71(55.9)$ & $56(44.1)$ & 2 & & 1.00 & - & - & - \\
\hline No answer & 0 & & & & & & & & \\
\hline \multicolumn{10}{|l|}{ Confidence in transplantation } \\
\hline $\begin{array}{l}\text { Do you believe that organ transplantation, when indicated, is a good } \\
\text { form of treatment for patients with end-stage organ disease? }\end{array}$ & & & & & $<0.001$ & & & & \\
\hline Yes & $325(78.9)$ & $236(72.8)$ & $88(27.2)$ & 1 & & $2.75(1.68-4.49)$ & $<0.001$ & $1.48(0.84-2.60)$ & 0.173 \\
\hline No/unsure & $86(20.9)$ & $42(49.4)$ & $43(50.6)$ & 1 & & 1.00 & - & - & - \\
\hline No answer & 1 & & & & & & & & \\
\hline $\begin{array}{l}\text { Would you accept a deceased donor organ for transplantation if you } \\
\text { had end-stage organ failure? }\end{array}$ & & & & & $<0.001$ & & & & \\
\hline Yes & 291 (70.6) & 225 (77.9) & $64(22.1)$ & 2 & & $4.36(2.77-6.86)$ & $<0.001$ & $3.20(1.97-5.21)$ & $<0.001$ \\
\hline No/unsure & $121(29.4)$ & $54(44.6)$ & $67(55.4)$ & 0 & & 1.00 & - & - & - \\
\hline No answer & 0 & & & & & & & & \\
\hline $\begin{array}{l}\text { In your opinion, is the success rate of transplantation high when } \\
\text { performed by trained personnel? }\end{array}$ & & & & & 0.001 & & & & \\
\hline Yes & $304(73.8)$ & $221(72.7)$ & $83(27.3)$ & 0 & & $2.20(1.39-3.48)$ & 0.001 & $1.29(0.77-2.18)$ & 0.333 \\
\hline No/unsure & $108(26.2)$ & $58(54.7)$ & $48(45.3)$ & 2 & & 1.00 & - & - & - \\
\hline No answer & 0 & & & & & & & & \\
\hline
\end{tabular}

*Percentages were calculated based on available data. aOR: adjusted odds ratio; Cl: confidence interval; COR: crude odds ratio 
Table V. Association of attitudes towards organ donation (OD) with willingness to donate.

\begin{tabular}{|c|c|c|c|c|c|c|c|}
\hline \multirow[t]{2}{*}{ Question } & \multirow[t]{2}{*}{ No. (\%) } & \multicolumn{3}{|c|}{$\begin{array}{l}\text { Willingness to } \\
\text { donate (no. [\%])* }\end{array}$} & \multirow[t]{2}{*}{ p-value } & \multicolumn{2}{|c|}{ Univariable analysis } \\
\hline & & Yes & $\begin{array}{l}\text { No/ } \\
\text { unsure }\end{array}$ & $\begin{array}{l}\text { No } \\
\text { answer }\end{array}$ & & COR (95\% Cl) & p-value \\
\hline \multicolumn{8}{|l|}{ Attitudes towards OD } \\
\hline $\begin{array}{l}\text { In your opinion, will families consent to have their relative's } \\
\text { organs donated after brain death has been confirmed? }\end{array}$ & & & & & 0.336 & & \\
\hline Yes & $203(49.3)$ & $142(70.3)$ & $60(29.7)$ & 1 & & $1.23(0.81-1.86)$ & 0.336 \\
\hline No/unsure & $209(50.7)$ & $137(65.9)$ & $71(34.1)$ & 1 & & 1.00 & - \\
\hline No answer & 0 & & & & & & \\
\hline $\begin{array}{l}\text { Deceased OD rates are low in this country. Do you think } \\
\text { this is because of a lack of counselling to families of } \\
\text { patients who are certified brain dead? }\end{array}$ & & & & & 0.099 & & \\
\hline Yes & $353(85.7)$ & $244(69.5)$ & $107(30.5)$ & 2 & & $1.61(0.91-2.85)$ & 0.102 \\
\hline No/unsure & $58(14.1)$ & $34(58.6)$ & $24(41.4)$ & 0 & & 1.00 & - \\
\hline No answer & 1 & & & & & & \\
\hline $\begin{array}{l}\text { If a patient has pledged to donate their organs without } \\
\text { their family's consent, families do not have the right to } \\
\text { refuse donation after the patient's death. }\end{array}$ & & & & & 0.087 & & \\
\hline Yes & $125(30.3)$ & $91(74.0)$ & $32(26.0)$ & 2 & & $1.51(0.94-2.41)$ & 0.088 \\
\hline No/unsure & $286(69.4)$ & $187(65.4)$ & $99(34.6)$ & 0 & & 1.00 & - \\
\hline No answer & 1 & & & & & & \\
\hline $\begin{array}{l}\text { Disfigurement will not occur to the deceased donor's } \\
\text { body during or after the process of donation. }\end{array}$ & & & & & 0.062 & & \\
\hline Yes & $185(44.9)$ & $133(72.7)$ & $50(27.3)$ & 2 & & $1.50(0.98-2.29)$ & 0.063 \\
\hline No/unsure & $225(54.6)$ & $144(64.0)$ & $81(36.0)$ & 0 & & 1.00 & - \\
\hline No answer & 2 & & & & & & \\
\hline
\end{tabular}

*Percentages were calculated based on available data. $\mathrm{Cl}$ : confidence interval; cOR: crude odds ratio

There was no statistically significant association between willingness to donate and $\mathrm{HCPs}^{\prime}$ beliefs regarding families' consent to OD (cOR 1.23, 95\% Cl 0.81-1.86, p = 0.336). Lack of family counselling $(p=0.102)$, the right to refuse OD $(p=0.088)$ and disfigurement after OD ( $p=0.063)$ were also not significantly associated with the willingness to donate (Table V).

Out of the 410 HCPs who responded, 279 (68.0\%) expressed their willingness to donate organs, but only 267 answered the question on informing their family about their wish to donate; $176(63.1 \%)$ responded that they had informed their family. Of the 279 HCPs who were willing to donate, only 104 (37.3\%) were carrying a donor card at the time of this study. Interestingly, six HCPs who answered 'No' or 'Unsure' regarding their willingness to donate also reported that they were carrying a donor card.

\section{DISCUSSION}

In contrast to previous studies in Malaysia, this study focused on HCPs caring for critically ill patients who may become eligible organ donors. We found that sociodemographic factors such as profession, religion and ethnicity were associated with HCPs' willingness to donate their own organs. Religious belief, belief in BD and confidence in transplantation were also associated with their willingness to donate. In Malaysia, willingness towards OD among HCPs in general was less than $50 \%$, as shown by Rozaidi et al and Abidin et al. ${ }^{(2,9)}$ In our study population, $68.0 \%$ were willing to donate. This difference may be due to the nature of the selected study population, which directly deals with OD. The majority of our HCP population from the critical care areas studied were nurses, who were significantly less willing to donate compared to doctors. Other studies have reported similar observations. ${ }^{(9,26,33}$

Malays of Muslim faith were the largest ethnic group in our study population, consistent with that of the general population in Malaysia. They were found to be significantly less willing to donate compared to other religions and ethnicities. Malays were observed to comprise only $6 \%$ of all donors although they form $68.6 \%$ of the population ${ }^{(34)}$ and have the potential to be the largest donor pool in Malaysia if their willingness to donate can be improved.

It has been shown that people are more willing to donate if they anticipate the support of a religious leader and the religious community. ${ }^{(35)}$ In one study, Islamic views supporting concepts of transplantation showed the strongest positive influence for OD both during life and at death. ${ }^{(36)}$ National and state fatwas (decrees) on OD have been issued in Malaysia, stating that OD was not forbidden in Islam. ${ }^{(37)}$ In one study, Malays who were aware of the correct Islamic fatwa on OD were shown to be more willing to donate.$^{(8)}$ One factor for the lower willingness to donate found in this study may be the inaccurate perception of OD among the Muslim community. ${ }^{(37)}$ In another local study, less than half of the Malays interviewed were aware that a fatwa on OD even existed, 
and one-third of those who were aware of its existence thought that the fatwa was against OD. ${ }^{(8)}$ Our results were similar to those of another study demonstrating that people who believed their religion did not allow OD showed no motivation to donate in the future. ${ }^{(35)}$ Therefore, clearing up the religious misconceptions of HCPs would improve their willingness to donate.

We found that the better the knowledge of HCPs, the more willing they were to donate, with BD test scores having the strongest correlation. This is consistent with international studies suggesting that HCPs who understand the concept of BD have more positive attitudes towards OD. ${ }^{(14,15,17)}$ It has been suggested that critical care nurses have inadequate knowledge of BD, OD and organ transplantation and that this may explain why they are less willing to donate..$^{(20,24,38)}$ In a study by Loch et al, some $\mathrm{HCPs}$ did not adequately understand the concept despite having tertiary education. ${ }^{(8)}$ Thus, educational programmes to improve understanding of $\mathrm{BD}$ and bedside tests for $\mathrm{BD}$ are urgently needed in the critical care setting.

Our study showed that HCPs with positive attitudes towards $\mathrm{BD}$ and confidence in transplantation were more willing to donate. HCPs were also more willing to donate if they were convinced of the existence of $\mathrm{BD}$, which is consistent with previous studies. ${ }^{(17)}$ Non-recognition of BD and misconceptions about BD were said to be factors that contributed to a shortage of organs from deceased donors. ${ }^{(9)}$ Misconceptions about BD may lead to aversion towards OD, which could affect $\mathrm{HCPs}^{\prime}$ own willingness to donate. ${ }^{(39)}$

The majority of the HCPs had confidence in transplantation and believed that it was a good form of treatment for endstage organ disease and were confident of the outcome of the procedure. However, in the multivariable logistic regression analysis shown in Table IV, the only variable that was associated with willingness to donate was their own inclination to accept an organ in the event of organ failure. This is consistent with results from similar studies in India and Qatar. ${ }^{(18,40)}$ Therefore, HCPs need to be convinced by the favourable outcomes of transplantation in order to be strong advocates for OD.

HCPs who believed there could be disfigurement after donation were as willing to donate as their counterparts. This is in contrast with other studies showing that only HCPs who were unconcerned about disfigurement were more inclined to donate. ${ }^{(14,15,40)}$ Even HCPs who thought that families had the right to refuse OD or that there was lack of counselling were willing to donate as compared to their counterparts. Overall, HCPs personal attitudes towards OD did not appear to influence their own willingness to donate.

Possession of an organ donor card has been studied as an indicator of HCPs' willingness to donate. ${ }^{(16,21)}$ Our study revealed that only $28.4 \%$ of HCPs possessed an organ donor card although most were willing to donate. This is in line with other studies that showed that possession of an organ donor card did not accurately reflect the actual number of HCPs willing to donate. . $^{(2,24,38,41)}$ Non-cognitive reasoning may have led to the belief that a donor card or discussion about OD carried bad luck ('jinx' factor) and was disgusting ('ick' factor). ${ }^{(42)}$ Moreover, medical distrust, desecration of bodily integrity and anticipated regret strengthen these potential barriers. ${ }^{(39,42)}$

As in other countries, families' consent is required in Malaysia for deceased OD. However, in our study, one-third of the HCPs who were willing to donate had not informed their family of their intention. Families who are unaware of the deceased person's wishes may refuse consent and potential donors can be lost.

Our study had a few limitations. It was conducted in Hospital Kuala Lumpur, which is the largest transplant centre in Malaysia. Although our high response rate and a good proportionate representation from different ethnicities added to the strength of the study, this was a single-centre study, and hence the data may not be representative of HCPs in the rest of Malaysia. Furthermore, knowledge and attitudes of family members of potential donors in critical care areas were not explored as part of this study. An understanding of these would shed light on factors such as their expectations, concerns and decision-making process in giving consent for their relatives' organs to be donated.

In conclusion, critical care HCPs can contribute to OD in various ways, including advocating for it. They should possess an adequate understanding of OD and the issues surrounding it, including BD as well as ethical, legal and religious issues. In our study, the willingness to donate of HCPs working in critical care areas was found to be higher than that of HCPs in general. However, significant knowledge gaps as well as certain beliefs and perceptions that could pose a barrier to OD were identified in this group. Although the majority of the HCPs were willing to donate their organs, one-third of them had not informed their families and nearly two-thirds did not possess an organ donor card. In future studies, targeted efforts to improve critical care HCPs' knowledge, attitudes and beliefs towards OD are needed to increase their willingness for OD. This is likely to influence their advocacy for OD and their approach to the families of potential OD patients in critical care units.

\section{ACKNOWLEDGEMENTS}

The authors would also like to thank Datin Dr Fadhilah Zowyah Lela Yasmin Mansor (National Transplant Resource Centre, Kuala Lumpur, Malaysia), Prof Karen Morgan and Assoc Prof Dr Manoj Valappil (Perdana University-Royal College of Surgeons in Ireland) for expert advice, Dr Yuzana Yusop (National Transplant Resource Centre, Kuala Lumpur, Malaysia) for forward translation to Malay, Dr Anne Jamaludin (Perdana University Royal College of Surgeons in Ireland) for back translation, Datuk Dr Noor Hisham Abdullah (Director General of Health, Ministry of Health, Malaysia) for allowing us to conduct this study, and the staff of Hospital Kuala Lumpur, Malaysia, for participating in this study.

\section{REFERENCES}

1. Consensus statement on brain death 2003. Malaysia: Ministry of Health Malaysia, Academy of Medicine of Malaysia, Malaysian Society of Neurosciences. Available at: http://www.moh.gov.my/images/gallery/orga/Consensus statement on brain death 2003.pdf. Accessed June 6, 2017.

2. Rozaidi SW, Sukro J, Dan A. The health care professional's attitudes towards brain death and cadaveric organ transplantation: the influence of cadaveric donor and transplantation programs--a Malaysian survey. Med J Malaysia 2000; 55:478-85. 
3. Surgical and Emergency Services Unit, Medical Services Development Section Medial Development Division, Ministry of Health Malaysia. National organ tissue and cell transplantation policy, June 2007. Available at: http://www.moh. gov.my/images/gallery/Polisi/National_Organ_Tissue_Cell_Transplan_Policy. pdf. Accessed June 7, 2018.

4. National Transplant Resource Centre. Role \& function of TOP team [unpublished lecture notes]. National Transplant Resource Centre; notes provided at lecture given 2018 Jun 6.

5. International Registry in Organ Donation and Transplant. Malaysia statistics 2015. Available at: http://www.irodat.org/?p=database \&c=MY\&year=2015\#data. Accessed June 14, 2017.

6. National Transplant Resource Centre. Organ donation statistics, updated January 2017. Available at: http://www.dermaorgan.gov.my/statistik-derma-organ/. Accessed June 14, 2017.

7. Global Observatory on Donation and Transplantation. Data (charts and tables) 2016. Available at: http://www.transplant-observatory.org/data-charts-andtables/chart/. Accessed July 8, 2017.

8. Loch A, Hilmi IN, Mazam Z, Pillay Y, Choon DSK. Differences in attitude towards cadaveric organ donation: observations in a multiracial Malaysian society. Hong Kong J Emerg Med 2010; 17:236-43.

9. Abidin ZL, Ming WT, Loch A, Hilmi I, Hautmann O. Are health professionals responsible for the shortage of organs from deceased donors in Malaysia? Transp Int 2013; 26:187-94.

10. Department of Statistics Malaysia. Current Population Estimates, Malaysia, 2014-2016. Available at: https://www.dosm.gov.my/v1/index.php?r=column/ cthemeByCat\&cat=155\&bul id=OWlxdEVoYlJCSOhUZzJyRUcvZEYxZz09\&menu id=LOpheU43NWJwRWVSZkIWdzQ4TIhUUT09. Accessed June 6, 2017.

11. Wong LP. Knowledge, attitudes, practices and behaviors regarding deceased organ donation and transplantation in Malaysia's multi-ethnic society: a baseline study. Clin Transplant 2011; 25:E22-31.

12. Makmor T, Abdillah N, Raja Noriza RA, et al. Low organ donation rate in Malaysia: a survey. J Health Transl Med 2014; 17:17.

13. Tumin M, Noh A, Mohd Satar N, et al. Organ donation in Muslim countries: the case of Malaysia. Ann Transplant 2013; 18:671-6.

14. Ríos ZA, Ramírez P, Martínez L, et al. Are personnel in transplant hospitals in favor of cadaveric organ donation? Multivariate attitudinal study in a hospita with a solid organ transplant program. Clin Transplant 2006; 20:743-54.

15. Ríos A, Conesa C, Ramírez P, et al. Attitude toward deceased organ donation and transplantation among the workers in the surgical services in a hospital with a transplant program. Transplant Proc 2005; 37:3603-8.

16. Radunz S, Hertel S, Schmid KW, et al. Attitude of health care professionals to organ donation: two surveys among the staff of a German university hospital. Transplant Proc 2010; 42:126-9.

17. Esezobor $\mathrm{Cl}$, Disu E, Oseni SB. Attitude to organ donation among healthcare workers in Nigeria. Clin Transplant 2012; 26:E612-6.

18. Alsaied O, Bener A, Al-Mosalamani Y, Nour B. Knowledge and attitudes of health care professionals toward organ donation and transplantation. Saudi J Kidney Dis Transpl 2012; 23:1304-10.

19. Topbaş M, Türkyilmaz S, Can G, et al. Information, attitude, and behavior toward organ transplantation and donation among health workers in the eastern Black Sea region of Turkey. Transplant Proc 2011; 43:773-7.

20. Demir T, Selimen D, Yildirim M, Kucuk HF. Knowledge and attitudes toward organ/tissue donation and transplantation among health care professionals working in organ transplantation or dialysis units. Transplant Proc 2011; 43:1425-8.

21. Siminoff LA, Arnold RM, Caplan AL. Health care professional attitudes toward donation: effect on practice and procurement. J Trauma 1995; 39:553-9.

22. Walters TP. Are front line health professionals responsible for the organ crisis? J Intensive Care Soc 2009; 10:201-6.
23. Domínguez-Gil B, Delmonico FL, Shaheen FA, et al. The critical pathway for deceased donation: reportable uniformity in the approach to deceased donation. Transpl Int 2011; 24:373-8.

24. Collins TJ. Organ and tissue donation: a survey of nurse's knowledge and educational needs in an adult ITU. Intensive Crit Care Nurs 2005; 21:226-33.

25. National Transplant Resource Centre. Process of donation. Available at: http:// www.dermaorgan.gov.my/process-of-donation/?lang=en. Accessed June 6 , 2018.

26. Roels L, Spaight C, Smits J, Cohen B. Critical care staffs' attitudes, confidence levels and educational needs correlate with countries' donation rates: data from the Donor Action database. Transpl Int 2010; 23:842-50.

27. Vandenbroucke JP, von Elm E, Altman DG, et al; STROBE Initiative. Strengthening the Reporting of Observational Studies in Epidemiology (STROBE): explanation and elaboration. Epidemiology 2007; 18:805-35.

28. Saleem T, Ishaque S, Habib N, et al. Knowledge, attitudes and practices survey on organ donation among a selected adult population of Pakistan. BMC Med Ethics 2009; 10:5.

29. Kim JR, Fisher MJ, Elliott D. Undergraduate nursing students' knowledge and attitudes towards organ donation in Korea: implications for education. Nurse Educ Today 2006; 26:465-74.

30. Sobnach V, Kahn D, John T, et al. A survey of medical students on their attitudes towards face transplantation. Int J Surg 2014; 12:45-50.

31. Chin KJ, Kwek TK, Lew TW. A survey of brain death certification--an impetus for standardisation and improvement. Ann Acad Med Singapore 2007; 36:987-94.

32. Wijdicks EF, Varelas PN, Gronseth GS, Greer DM; American Academy of Neurology. Evidence-based guideline update: determining brain death in adults: report of the Quality Standards Subcommittee of the American Academy of Neurology. Neurology 2010; 74:1911-8.

33. Bøgh L, Madsen M. Attitudes, knowledge, and proficiency in relation to organ donation: a questionnaire-based analysis in donor hospitals in northern Denmark. Transplant Proc 2005; 37:3256-7.

34. Mansor LY, Hooi LS. Chapter 8: Deceased (cadaveric) organ and tissue donation. In: the 11th Report of the National Transplant Registry 2014. Available at: http:// www.mst.org.my/ntrSite/donwload/report2014/2014_Chapter8_Cadaveric.pdf. Accessed June 7, 2017

35. Skowronski JJ. On the psychology of organ donation: attitudinal and situational factors related to the willingness to be an organ donor. Basic Appl Soc Psych 1997; 19:427-56

36. al-Faqih SR. The influence of Islamic views on public attitudes towards kidney transplant donation in a Saudi Arabian community. Public Health 1991; 105:161-5.

37. Ministry of Health Malaysia. Organ transplantation from the Islamic perspective. Available at: http://www.moh.gov.my/images/gallery/orga/edu/awam/Organ_ TranlsmEN.pdf. Accessed June 7, 2017.

38. Akgün HS, Bilgin N, Tokalak I, Kut A, Haberal M. Organ donation: a crosssectional survey of the knowledge and personal views of Turkish health care professionals. Transplant Proc 2003; 35:1273-5.

39. O'Carroll RE, Foster C, McGeechan G, Sandford K, Ferguson E. The "ick" factor, anticipated regret, and willingness to become an organ donor. Health Psychol $2011 ; 30: 236-45$

40. Ahlawat R, Kumar V, Gupta AK, et al. Attitude and knowledge of healthcare workers in critical areas towards deceased organ donation in a public sector hospital in India. Natl Med J India 2013; 26:322-6.

41. Arjmand B, Aghayan SH, Goodarzi P, et al. Knowledge and attitude of donor cardholders toward organ and tissue donation and transplantation in an Iranian tissue bank: a case-control study. Transplant Proc 2009; 41:2715-7.

42. Morgan SE, Stephenson MT, Harrison TR, Afifi WA, Long SD. Facts versus 'feelings': how rational is the decision to become an organ donor? J Health Psychol 2008; 13:644-58. 